Indonesian Journal of
Mathematics and Natural Sciences Education
p-ISSN: 2721-172X e-ISSN: 2721-1746
Vol. 2 No. 1 Th 2020; Hal 136-149
http://mass.iain-jember.ac.id

\title{
Pengembangan Media Pembelajaran Video Bus Math (Business Mathematic) Pada Materi Barisan dan Deret
}

\author{
Enny Listiawati ${ }^{1}$, Nurul Komariyah ${ }^{1}$ \\ ${ }^{1}$ STKIP PGRI Bangkalan. Jl. Soekarno Hatta No 52 Bangkalan, \\ * E-mail: ennylistiawati@ stkippgri-bkl.ac.id ${ }^{1}$
}

\begin{abstract}
Abstrak
Penelitian ini bertujuan untuk mengembangkan dan mengetahui keefektifan media pembelajaran video bus math memakai aplikasi video scribe berbasis saintifik pada materi barisan dan deret. Jenis penelitian yang digunakan Research And Development (R\&D) dengan metode pengembangan memakai model pengembangan 4-D (four $\mathrm{D}$ model) dengan tahap pengembangan yang hanya memakai sampai 3 tahap saja, yaitu: (1) pendefinisian (define), (2) perancangan (design), dan (3) pengembangan (develop). Hasil penelitian dapat disimpulkan bahwa pengembangan media pembelajaran video bus math (business mathematic) memakai aplikasi video scribe berbasis saintifik pada materi barisan dan deret dengan memakai model pengembangan 4-D yang dilakukan untuk mendapatkan media pembelajaran yang baik dan efektif pada materi barisan dan deret kelas XI karena memenuhi (1) kategori valid dengan oleh rata-rata persentase $87 \%$ atau layak dan ahli media diperoleh rata-rata persentase $85 \%$ atau layak, (2) kategori efektif untuk kemampuan guru mengelola pembelajaran dengan skor rata-rata 3,7 atau sangat baik, (3) kategori efektif untuk aktivitas siswa dalam pembelajaran memperoleh hasil 7 aspek aktivitas siswa dalam kriteria batasan efektif, (4) kategori positif untuk respons siswa diperoleh persentase semua aspek di atas 80\%, dan (5) kategori ketuntasan secara klasikal untuk hasil belajar siswa telah mencapai ketuntasan secara klasikal 87,5\%.
\end{abstract}

Kata Kunci: Bus Math, Media Pembelajaran, Pengembangan.

\begin{abstract}
This study aims to develop and determine the effectiveness of bus math video learning media using scientific-based video scribe applications on sequences and series subject. This type of research used Research and Development (R\&D) with the development method using a 4-D (four D model) development model with a development phase that only uses up to 3 stages, namely: (1) defining, (2) designing, and (3) development. The results of the study can be concluded that the development of video bus math (business mathematic) learning media uses scientific-based video scribe applications on row and series material by using the 4-D development model which is carried out to get good and effective learning media on class XI material and series because it meets (1) a valid category with an average percentage of $87 \%$ and media experts obtained an average percentage of $85 \%$, (2) an effective category for teachers' ability to manage learning with an average score of 3.7, (3) effective categories for student activities in learning get 7 aspects of student activity results in the criteria of effective limits, (4) positive categories for student responses obtained percentage of all aspects above $80 \%$, and (5) classical completeness category for student learning outcomes has reached classical completeness $87.5 \%$.
\end{abstract}

Keywords: Bus Math, Learning Media, Development. 


\section{PENDAHULUAN}

Pada pengembangan kurikulum tahun 2013 ada perubahan pendekatan pembelajaran yaitu memakai pendekatan saintifik (Nurdyansyah, 2015). Proses pembelajaran dengan pendekatan saintifik meliputi langkahlangkah mengamati, menanya, mencoba, mengasosiasi dan mengomunikasikan. Nyatanya masih banyak guru yang mengalami kesusahan untuk melakukan langkah-langkah sesuai dengan mata pelajaran yang diajarkan. Hal ini menunjukkan bahwa guru masih belum memahami dengan baik konsep tentang langkah-langkah pendekatan saintifik dalam pembelajaran (Prihadi, 2014). Guru bisa menggunakan teknologi, khususnya komputer dan internet yang dapat membantu meningkatkan daya tarik siswa dalam belajar. Proses belajar Matematika memerlukan media yang mudah dimengerti oleh siswa (Oktavianingrum, 2016).

Hasil wawancara dengan salah satu guru matematika di SMA Ar-Raudhah diperoleh bahwa metode yang dipakai di kelas menggunakan metode secara langsung dan pemakaian media pembelajaran kurang dan terbatas. Kurangnya media yang memadai ini membuat siswa kurang tertarik dan semangat dalam belajar. Selain itu, dari banyak siswa 40 terdapat $45 \%$ siswa yang mendapatkan nilai belum mencapai KKM. Berdasarkan penjabaran diatas bisa disimpulkan bahwa kurangnya penggunaan media pembelajaran yang baru di zaman modern saat ini membuat siswa lebih cepat bosan dengan media yang lama sehingga membuat siswa kurang aktif dalam kegiatan belajar mengajar. Inilah yang membuat peneliti untuk mengembangkan media pembelajaran yang bisa membuat siswa tertarik dan minat belajar sehingga diharapkan lebih aktif dan mudah dimengerti dalam proses pembelajaran.

Penjelasan materi pembelajaran tersebut ditunjang melalui desain gambar tiga dimensi yang dapat memperjelas materi. Media tersebut bisa seperti video (Oktavianingrum, 2016). Media pembelajaran yang bisa menunjang dan mengatasi masalah tersebut salah satunya adalah video Bus Math. Didalam video Bus Math terdapat materi dengan gambar, garis, simbol, suara dan gerakan yang dibuat menarik. Video Bus Math adalah video yang dibuat memakai aplikasi Video Scribe Sparkol. Video Scribe Sparkol adalah aplikasi lunak yang menghasilkan video yang dapat dikombinasikan dengan peta konsep, gambar - gambar, suara, dan musik yang dapat membuat siswa tertarik dan meningkatkan minat siswa untuk mengamati pelajaran secara aktif (Kholidin, 2017).

Berdasarkan penjelasan tersebut maka tujuan penelitian ini untuk mengembangkan dan mengetahui keefektifan media pembelajaran video Bus Math menggunakan aplikasi video scribe berbasis saintifik pada materi barisan dan deret.

\section{KAJIAN TEORI}

\section{Media Pembelajaran}

Media pembelajaran adalah sarana komunikasi yang membuat siswa tertarik dapat dipakai antara guru dengan peserta didik untuk menambah 
ketertarikan siswa dalam pembelajaran (Taufiq, 2016). Fransisca (2018) juga berpendapat media pembelajaran dapat membantu untuk mengkomunikasikan pesan pada siswa agar lebih mudah dimengerti dan membuat perhatian siswa lebih terfokus mengikuti pembelajaran.

Berdasarkan definisi di atas, maka bisa disimpulkan bahwa media pembelajaran pada penelitian ini adalah segala sesuatu yang dapat digunakan sebagai komunikasi informasi yang lebih membuat siswa tertarik sehingga tujuan pembelajaran tercapai.

\section{Video Business Mathematic (Bus Math) memakai aplikasi Videoscribe}

Video scribe merupakan software yang menghasilkan animasi gaya papan tulis singkat untuk menjelaskan konsepkonsep tertentu baik dibuat oleh instruktur (guru) dan siswa (Dellyardianzah, 2017). Menurut Sutrisno (2016) kelebihan video scribe sparkol adalah program aplikasi yang sering dipakai di sekolah untuk media pembelajaran agar dalam proses pembelajaran lebih menarik dan mudah disampaikan kemudian agar kegunaan program video scribe sparkol bisa meningkatkan stimulus, kreativitas dan produktivitas siswa dalam proses pembelajaran sedangkan kelemahannya penggunaan video dalam proses pembelajaran bisa menimbulkan sifat komunikasi satu arah dan dalam proses penayangan video diperlukan peralatan yang kompleks serta pada saat pembuatan video membutuhkan waktu yang cukup lama.

Media videoscribe yaitu, sebuah video animasi tangan bergerak, menulis dan menggambar pada whiteboard yang dapat berubah-ubah warnanya sesuai dengan keinginan pengguna media tersebut (Rochmah, 2017).

Berdasarkan definisi di atas, maka bisa disimpulkan bahwa Video Business Mathematic (Bus Math) menggunakan aplikasi videoscribe dalam penelitian ini adalah video pembelajaran animasi yang digunakan untuk menjelaskan konsepkonsep tertentu bisa dibuat oleh instruktur (guru) dan siswa yang bisa menampilkan berupa foto, gambar, teks, musik, dan background yang bisa dipilih sesuai keinginan.

\section{Pendekatan Saintifik}

Daryanto (2014) berpendapat pendekatan saintifik, yaitu pendekatan yang memakai langkah-langkan serta kaidah ilmiah dalam proses pembelajaran. Langkah ilmiah yang dipakai sebagai berikut : menemukan masalah, merumuskan masalah, mengajukan hipotesis, mengumpulkan data, menganalisis data, dan menarik kesimpulan. Pendekatan saintifik yang dimaksud untuk memberi penjelasan pada siswa agar mengetahui, memahami, mempraktikkan apa yang sedang dipelajari secara ilmiah. Oleh karena itu, dalam pembelajaran diajarkan agar siswa mencari tahu dari bermacam sumber melalui mengamati, menanya, mencoba, mengolah, menyajikan, menyimpulkan, dan mencipta untuk seluruh mata pelajaran. Siswa dijadikan pusat belajar, tidak dijadikan obyek pembelajaran. Dengan demikian karakter, skill, serta kognisi siswa bisa dikembangkan secara optimal (Musfiqon, 2015).

Dari definisi yang telah dikemukakan maka dapat disimpulkan bahwa pendekatan saintifik dalam 
penelitian ini adalah suatu pendekatan yang melalui tahap proses pembelajaran dari mengamati, menanya, mencoba, mengasosiasi, dan mengomunikasikan.

\section{METODE}

Menurut (Sugiyono, 2012) Metode penelitian dan pengembangan adalah metode penelitian yang digunakan untuk menghasilkan produk tertentu dan produk tersebut diuji keefektifannya. Borg \& Gall (1983) mengemukakan bahwa penelitian pengembangan adalah proses yang dipakai untuk mengembangkan dan memvalidasi produk-produk pendidikan.

Subjek dalam penelitian ini adalah siswa yang sebanyak 40 dan guru matematika kelas XI MIPA 2 SMA ArRaudhah Sebaneh Bangkalan. Dilaksanakan pada bulan April 2019.

Model pengembangan 4-D (Four D) tahap utama yaitu pendefinisian (define), perencanaan (design), pengembangan (develop), dan (disseminate) (Trianto, 2014). Dalam penelitian ini terdapat penyederhanaan tahap pengembangan yang terdiri dari tiga tahap, yaitu: (1) pendefinisian (define), (2) perencanaan (design), dan (3) pengembangan (develope). Jadi tidak sampai pada tahap penyebaran (disseminate) karena pada sampai tahap 3 sudah dapat dihasilkan media yang diinginkan.

Tahap-tahap pengembangan media pembelajaran tersebut dijelaskan sebagai berikut: 1. Tahap Pendefinisian (Define) bertujuan mencari dan menetapkan permasalahan yang ada dengan cara melaksanakan analisis tujuan dalam bahasan materi yang dikembangkan.
Kegiatan dalam tahap ini meliputi (1) analisis awal-akhir, (2) analisis siswa, (3) analisis materi, (4) analisis tugas, dan (5) perumusan indikator pencapaian hasil belajar. 2. Tahap Perancangan (Design) bertujuan mendapatkan rancangan media pembelajaran. Hasil yang didapatkan pada tahap perancangan ini disebut draf I. Kegiatan yang dilaksanakan pada tahap ini meliputi: (1) pemilihan media, (2) pemilihan format, (3) perancangan awal media pembelajaran berupa video Business Mathematic (Bus Math) memakai aplikasi video scribe. 3. Tahap Pengembangan (Develop) bertujuan untuk mendapatkan draf final, yaitu draf media pembelajaran yang sudah direvisi berdasarkan masukan para ahli (validator) dan data dari uji coba lapangan. Kegiatan pada tahap ini meliputi. a) Validasi Ahli diperoleh dari para ahli (yang dianggap berkompeten) seperti dosen pendidikan matematika, mahasiswa S3 pendidikan matematika, dan guru matematika sebagai masukan atau saran demi kesempurnaan media pembelajaran. Hasil validasi ini dianalisis dan dipakai untuk bahan pertimbangan dalam merevisi draf I. Media pembelajaran yang sudah direvisi berdasarkan hasil validasi disebut draf II. b) Hasil Uji coba Lapangan sesudah diperoleh draf II, kemudian diujicobakan. Kegiatan ini bertujuan untuk mendapatkan masukan langsung dari lapangan terhadap media pembelajaran yang sudah disusun. Hasil uji coba dianalisis dan dipakai untuk bahan pertimbangan sebagai acuan merevisi draf II. Hasil revisi draf II kemudian disebut draf final. Uji coba produk dilaksanakan dengan desain uji coba. 
Media pembelajaran yang baik ditinjau dari kemampuan guru mengelola pembelajaran, kesesuaian aktivitas siswa dengan alokasi waktu, respons positif siswa dan tes hasil belajar (Sari, 2018). Dalam uji coba ini, seluruh komentar dan saran dari guru, siswa dan pengamat dicatat untuk masukan sebagai acuan revisi media draf II menjadi draf final. Jika hasil uji coba menunjukkan draf II belum memenuhi kriteria media yang baik, maka draf II direvisi menjadi draf II $(j)(j \geq 1)$. Draf II (j) diujicobakan kembali.

\section{Instrumen Penelitian}

Dalam penelitian ini memakai instrumen penelitian yang meliputi : 1 . Lembar validasi media pembelajaran berupa lembar evaluasi media pembelajaran yang diserahkan pada pakar atau ahli yang terdiri dari ahli materi dan ahli media bertujuan untuk mengetahui kelayakan media sebagai media pembelajaran matematika sebelum digunakan. 2. Angket respons siswa berupa lembar evaluasi media yang diserahkan pada siswa bertujuan untuk mengetahui respons dari siswa terhadap media pembelajaran matematika pada saat uji coba kelompok untuk sampel sebagai acuan mengetahui apakah media pembelajaran matematika yang dikembangkan tersebut sudah baik atau tidak. 3. Lembar pengamatan kemampuan guru mengelola pembelajaran dipakai sebagai penilaian kemampuan guru mengelola kelas dengan menggunakan media pembelajaran video Business Mathematic (Bus Math) memakai aplikasi video scribe berbasis saintifik. 3. Lembar pengamatan aktivitas siswa dipakai sebagai penilaian sikap untuk mengukur aktivitas belajar siswa selama kegiatan uji coba dengan memakai media pembelajaran video Business Mathematic (Bus Math) memakai aplikasi video scribe berbasis saintifik yang dilaksanakan pada kegiatan pembelajaran. 4. Tes Hasil Belajar (THB) dipakai untuk mengetahui ketuntasan belajar siswa sesudah mengikuti pembelajaran dengan media pembelajaran video Business Mathematic (Bus Math) memakai aplikasi video scribe berbasis saintifik pada materi barisan dan deret aritmetika.

\section{Teknik Pengumpulan Data}

Dalam penelitian ini memakai teknik pengumpulan data : 1. Teknik Angket : a) Lembar validasi media pembelajaran, b) Angket respons siswa. 2. Teknik observasi : a) Lembar pengamatan kemampuan guru mengelola pembelajaran, b) Lembar pengamatan aktivitas siswa. 3. Teknik Tes Hasil Belajar (THB).

\section{Teknik Analisis Data}

1. Analisis Data Validasi

$P=\frac{\sum x_{i}}{\sum x} x 100 \%$

Keterangan:

$P \quad$ : persentase

$\sum x_{i}$ : Jumlah skor jawaban validator

$\sum x$ : Jumlah skor maksimal

Tabel 1. Kategori Batas Validasi

\begin{tabular}{cll}
\hline No. & \multicolumn{1}{c}{ Persentase } & Keterangan \\
\hline 1. & $\begin{array}{l}80 \% \leq p \\
\leq 100 \%\end{array}$ & $\begin{array}{l}\text { Layak dan } \\
\text { tidak perlu } \\
\text { revisi }\end{array}$ \\
\hline 2. & $\begin{array}{l}60 \% \leq p \\
<80 \%\end{array}$ & $\begin{array}{l}\text { Cukup layak } \\
\text { dan tidak } \\
\text { perlu revisi }\end{array}$ \\
\hline 3. & $\begin{array}{l}50 \% \leq p \\
<60 \%\end{array}$ & $\begin{array}{l}\text { Kurang layak } \\
\text { dan perlu } \\
\text { revisi }\end{array}$ \\
\hline
\end{tabular}




\begin{tabular}{ccc}
\hline $\begin{array}{cc}0 \% \leq p \\
<50 \%\end{array}$ & $\begin{array}{l}\text { Tidak layak } \\
\text { dan harus } \\
\text { revisi total }\end{array}$ \\
\hline Diadaptasi dari (Sudjana, 2011).
\end{tabular}

2. Data Kemampuan Guru dalam Mengelola Pembelajaran

$$
\text { Skor rata }- \text { rata }=\frac{\text { skor }}{\text { Jumlah }}
$$

kategori rata-rata skor

$1,00 \leq$ Rata-rata $\leq 1,50$ : sangat tidak baik

$1,50<$ Rata-rata $\leq 2,50$ : tidak baik

$2,50<$ Rata-rata $\leq 3,50 \quad$ : baik

$3,50<$ Rata-rata $\leq 4,00$ : sangat baik

Diadaptasi dari (Sudjana, 2011).

3. Analisis Data Aktivitas Siswa

Persentase $=\frac{\text { Frekuensi }}{\text { Jumlah frekuensi }} \times 100 \%$

Tabel 2. Kriteria Batas Efektivitas Aktivitas Siswa dalam Pembelajaran

\begin{tabular}{|c|c|}
\hline Aspek & $\begin{array}{c}\text { Persentase } \\
\text { Kesesuaian (P) }\end{array}$ \\
\hline $\begin{array}{l}\text { pengamatan } \\
\text { aktivitas siswa }\end{array}$ & $\begin{array}{cc}\text { Waktu } & \text { Interval } \\
\text { Ideal } & \text { Toleransi } \\
\end{array}$ \\
\hline
\end{tabular}

\begin{tabular}{lcc}
\hline $\begin{array}{l}\text { Memperhatikan } \\
\text { dan mendengarkan }\end{array}$ & 20 & $19-21$ \\
$\begin{array}{l}\text { guru dan siswa lain } \\
\text { Membentuk }\end{array}$ & 7,14 & $6,78-$ \\
kelompok & 7,5 \\
\hline $\begin{array}{l}\text { Memperhatikan dar } \\
\text { mengamati videc }\end{array}$ & $20,36-$ \\
$\begin{array}{l}\text { yang diberikan guru } \\
\text { 21,43 }\end{array}$ & 22,5 \\
$\begin{array}{l}\text { yang berisi tentang } \\
\text { materi pembelajaran }\end{array}$ & \\
\hline $\begin{array}{l}\text { Menanyakan } \\
\text { kepada guru yang } \\
\text { belum dimengerti }\end{array}$ & 14,28 & $13,57-$ \\
\hline
\end{tabular}

\begin{tabular}{lcc}
\hline $\begin{array}{l}\text { Menyelesaikan } \\
\text { permasalahan atau } \\
\text { tugas yang terdapat } \\
\text { pada LKS }\end{array}$ & 11,43 & $\begin{array}{c}10,86- \\
12\end{array}$ \\
\hline $\begin{array}{l}\text { Siswa berdiskusi } \\
\text { Siswa }\end{array}$ & 11,43 & $\begin{array}{c}10,86- \\
12\end{array}$ \\
\hline $\begin{array}{l}\text { mempresentasikan } \\
\text { hasil pekerjaannya }\end{array}$ & 14,28 & $\begin{array}{c}13,57- \\
15\end{array}$ \\
\hline $\begin{array}{l}\text { Perilaku yang tidak } \\
\text { relevan }\end{array}$ & 0 & $0-5$ \\
\hline
\end{tabular}

Diadaptasi dari (Sari, 2018)

4. Analisis Data Respons Siswa

Persentase $=\frac{\text { Jumlah respon positif }}{\text { Jumlah seluruh siswa }}$

Diadaptasi dari (Sari, 2018)

5. Analisis Data Tes Hasil Belajar Siswa

$$
\begin{gathered}
\mathrm{KI}=\frac{\text { skor yang diperoleh }}{\text { skor maksimal }} \times 100 \\
\mathrm{PTK}=\frac{\sum \mathrm{T}}{\sum \mathrm{S}} \times 100 \%
\end{gathered}
$$

Keterangan :

$\mathrm{KI}=$ ketuntasan individu

PTK = persentase tuntas klasikal

$\sum T=$ jumlah siswa yang tuntas

$\sum S=$ jumlah siswa seluruhnya

Diadaptasi dari (Ritna, 2013)

\section{HASIL DAN PEMBAHASAN}

Hasil dan pembahasan pengembangan media pembelajaran video bus math memakai aplikasi video scribe terdapat penyederhanaan model pengembangan 4-D menjadi tahap pengembangan yang terdiri dari tiga tahap, yaitu: (1) pendefinisian (define), (2) perencanaan (design), dan (3) pengembangan (develope). Jadi tidak sampai pada tahap penyebaran (disseminate) karena pada sampai pada 
tahap 3 sudah dapat dihasilkan media yang diinginkan.

Hasil tahap pendefinisian (define) : 1 . Analisis awal-akhir berupa analisis kurikulum mata pelajaran matematika, observasi awal dengan bertanya kepada guru matematika dan mengamati proses belajar matematika di SMA Ar Raudhah Sebaneh. 2. Analisis siswa meliputi analisis karakteristik siswa dan pengembangan kognitif siswa. 3. Analisis materi sesuai dengan KI dan KD. 4. Analisis tugas mengidentifikasi keterampilan utama sesuai KD. 5. Perumusan indikator pencapaian hasil belajar dengan melakukan perumusan hasil analisis awal akhir, analisis siswa, analisis tugas dan analisis materi di atas menjadi tujuan pencapaian hasil belajar.

Hasil Tahap Perancangan (Design) : 1. Pemilihan media dengan memilih dan menentukan media yang tepat untuk penyajian materi pelajaran yang disesuaikan dengan analisis tugas, analisis konsep, analisis siswa, dan perumusan indikator pencapaian hasil belajar seperti gambar, musik, suara dan lain-lain yang mendukung pembuatan video. 2. Pemilihan format dengan merancang isi, pemilihan strategi pembelajaran dan sumber belajar. 3 . Desain awal media pembelajaran membuat rancangan awal video yang berisi tentang materi yang ditampilkan pada saat uji coba. Hasil tahap ini berupa desain awal media pembelajaran yang merupakan draf I berserta instrumen penelitian. 1) Desain Awal Video Bus Math (Business Mathematic) sebagai berikut :

(a) Pada tampilan awal mencantumkan nama video



Gambar 1 Tampilan Awal

(b) Peneliti pada tampilan selanjutnya mencantumkan materi yang akan di bahas.

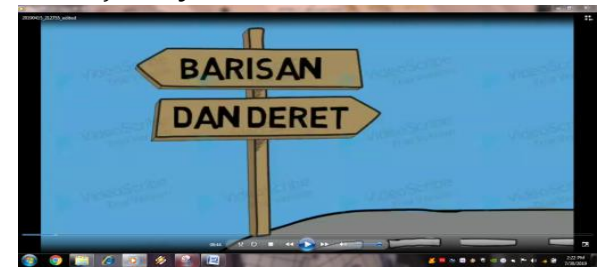

Gambar 2 Tampilan Judul Materi

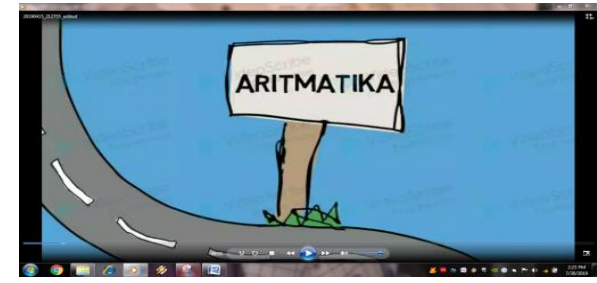

Gambar 3 Tampilan Materi Pokok Pembahasan 
(c) Tampilan simulasi penerapan dalam kehidupan sehari-hari.

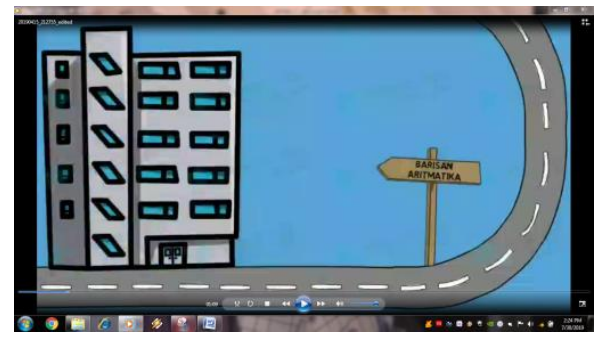

Gambar 4 Tampilan Simulasi

(d) Tampilan isi materi barisan aritmetika



Gambar 5 Tampilan Materi Barisan Aritmetika

(e) Tampilan contoh soal barisan aritmetika

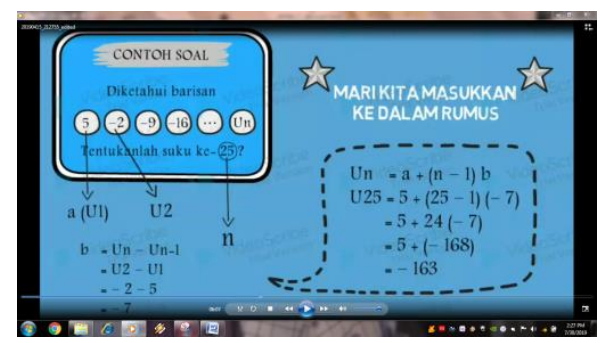

Gambar 6 Tampilan Contoh Soal Barisan Aritmetika

(f) Tampilan isi materi deret aritmetika

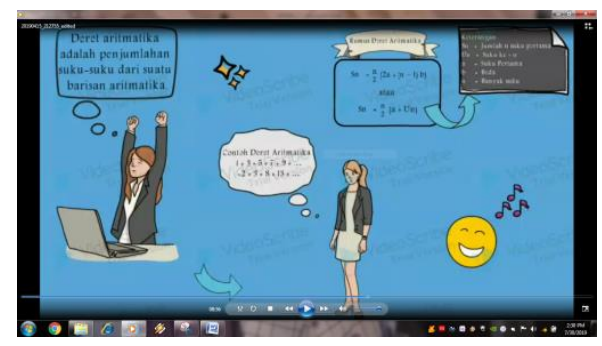

Gambar 7 Tampilan Materi Deret Aritmetika

(g) Tampilan contoh soal deret aritmetika

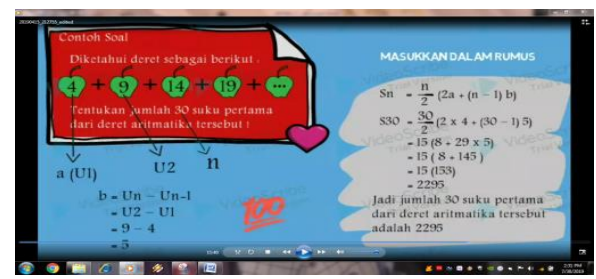

Gambar 8 Tampilan Contoh Soal Deret Aritmetika 
(h) Tampilan contoh soal barisan dan deret aritmetika penerapan dalam kehidupan sehari-hari

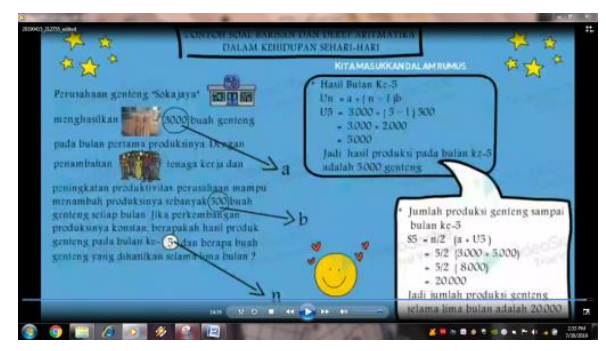

Gambar 9 Tampilan Contoh Soal Kehidupan Sehari-hari

(i) Tampilan akhir ucapan terima kasih



Gambar 10 Tampilan Akhir

2) Menyusun tes hasil belajar (THB) dirancang berupa tes uraian dan terdiri dari 3 soal yang berpedoman pada indikator pencapaian untuk mengukur keterbacaan dari hasil pengembangan.

Hasil tahap pengembangan (Develop) yaitu:

1. Validasi ahli dilaksanakan uji validitas media pembelajaran video dapatkan dari hasil penilaian para validator. Analisis data validitas dari ahli materi yang dilakukan mendapatkan ratarata persentase $87 \%$ dan dari ahli media yang dilakukan mendapatkan rata-rata persentase $85 \%$ sehingga disimpulkan bahwa media tersebut berada dalam kategori layak dan tidak perlu revisi.

2. Ujicoba lapangan,

a. Ujicoba lapangan perorangan, persentase setiap aspek pada ujicoba perorangan dari segi respon siswa setiap aspek lebih dari $80 \%$ sehingga dapat disimpulkan bahwa respons siswa pada media pembelajaran yang dikembangkan adalah positif.

b. Uji coba lapangan satu kelas

1) Hasil analisis data pengamatan kemampuan guru mengelola pembelajaran dapat dilihat pada tabel. Dari tabel dapat dilihat bahwa skor rata-rata yang diperoleh adalah 3,7 jadi disimpulkan bahwa hasil pengamatan berada pada kategori sangat baik sehingga dikatakan efektif.

Tabel 3 Data Kemampuan Guru

\begin{tabular}{lc}
\hline \multicolumn{1}{c}{ Aspek yang diamati } & Skor \\
\hline Pendahuluan & \\
\hline $\begin{array}{l}\text { 1. Mengingat kembali } \\
\text { materi sebelumnya }\end{array}$ & 4 \\
\hline
\end{tabular}




\begin{tabular}{|c|c|}
\hline $\begin{array}{l}\text { 2. Menyampaikan } \\
\text { tujuan pembelajaran }\end{array}$ & 3 \\
\hline 3. Memotivasi siswa & 4 \\
\hline \multicolumn{2}{|l|}{ Kegiatan Inti } \\
\hline $\begin{array}{l}\text { 1. Kemampuan } \\
\text { menjelaskan materi }\end{array}$ & 4 \\
\hline 2. Penguasaan materi & 4 \\
\hline $\begin{array}{l}\text { 3. Kemampuan } \\
\text { menjelaskan } \\
\text { pemberian masalah } \\
\text { kontekstual pada } \\
\text { siswa yang dikemas } \\
\text { pada video bus math } \\
\text { (business mathematic) } \\
\text { menggunakan } \\
\text { aplikasi video scribe }\end{array}$ & 4 \\
\hline $\begin{array}{l}\text { 4. Kemampuan guru } \\
\text { membimbing siswa } \\
\text { agar menemukan } \\
\text { sendiri konsep dan } \\
\text { penyelesaiannya } \\
\text { dalam } \\
\text { menyelesaikan } \\
\text { masalah } \\
\text { kontekstual } \\
\end{array}$ & 3 \\
\hline $\begin{array}{l}\text { 5. Kemampuan guru } \\
\text { mengamati siswa } \\
\text { dalam berinteraksi } \\
\text { di dalam kelas } \\
\text { untuk } \\
\text { menyelesaikan } \\
\text { masalah yang } \\
\text { diberikan }\end{array}$ & 3 \\
\hline $\begin{array}{l}\text { 6. Kemampuan } \\
\text { menghargai } \\
\text { pendapat siswa } \\
\text { menyampaikan } \\
\text { jawaban dalam } \\
\text { menyelesaikan } \\
\text { masalah yang } \\
\text { diberikan guru }\end{array}$ & 4 \\
\hline
\end{tabular}

7. Kemampuan guru
memotivasi siswa
untuk mau bertanya
dan memberikan
pendapat dalam 4
menanggapi
berbagai jawaban-
jawaban di kelas

8. Kemampuan guru dalam membimbing siswa untuk menarik kesimpulan dan siswa menemukan sendiri konsep dan penyelesaian dari permasalahan tersebut

Penutup

1. Kemampuan guru menegaskan hal-hal penting/ kesimpulan berkaitan dengan pembelajaran

2. Kemampuan memberikan penguatan kepada siswa

3. Kemampuan menutup pembelajaran

\section{Kemampuan} mengelola waktu

Kemampuan guru membuat pembelajaran interaktif dan suasana

kelas hidup 
2) Ujicoba kelas dari segi respon siswa setiap aspek lebih dari $80 \%$ sehingga bisa disimpulkan bahwa respons siswa pada media pembelajaran yang dikembangkan adalah positif. Hasil respons siswa dapat dilihat pada tabel 4 .

Tabel 4. Hasil Persentase Respon Siswa

\begin{tabular}{|c|c|c|c|}
\hline \multirow[t]{2}{*}{ Pernyataan } & \multicolumn{2}{|c|}{$\begin{array}{c}\text { Respons } \\
\text { Siswa }\end{array}$} & \multirow{2}{*}{$\begin{array}{c}\text { Persentase } \\
\text { Respons } \\
\text { Positif }\end{array}$} \\
\hline & Ya & idak & \\
\hline $\begin{array}{l}\text { Video ini } \\
\text { menarik dan } \\
\text { membuat saya } \\
\text { ingin tahu } \\
\text { lebih banyak } \\
\text { lagi tentang } \\
\text { barisan dan } \\
\text { deret } \\
\text { aritmetika }\end{array}$ & 47 & 3 & $94 \%$ \\
\hline $\begin{array}{l}\text { Video ini } \\
\text { menyenangkan } \\
\text { sehingga } \\
\text { membuat lebih } \\
\text { semangat } \\
\text { dalam belajar } \\
\text { matematika } \\
\end{array}$ & 47 & 3 & $94 \%$ \\
\hline $\begin{array}{l}\text { Video ini } \\
\text { memiliki } \\
\text { warna, gambar } \\
\text { dan tampilan } \\
\text { yang menarik } \\
\text { dan tidak } \\
\text { membosankan }\end{array}$ & 50 & 0 & $100 \%$ \\
\hline $\begin{array}{l}\text { Video ini } \\
\text { menggunakan } \\
\text { bahasa yang } \\
\text { jelas dan } \\
\text { sederhana } \\
\end{array}$ & 44 & 6 & $88 \%$ \\
\hline
\end{tabular}

\begin{tabular}{|c|c|c|}
\hline $\begin{array}{cr}\text { Aspek } & \mathrm{Pe} \\
\text { Pengamatan } & \mathrm{A}\end{array}$ & $\begin{array}{l}\text { Persentase } \\
\text { Aktivitas } \\
\text { Siswa }\end{array}$ & $\begin{array}{c}\text { Toleransi } \\
\text { Keefektif } \\
\text { an }(\%)\end{array}$ \\
\hline $\begin{array}{l}\text { Memperhatik } \\
\text { an dan } \\
\text { mendengarka } \\
\text { n guru dan } \\
\text { siswa lain }\end{array}$ & 20,24 & $19-21$ \\
\hline $\begin{array}{l}\text { Membentuk } \\
\text { kelompok }\end{array}$ & 7,14 & $6,78-7,5$ \\
\hline $\begin{array}{l}\text { mengamati } \\
\text { video yang } \\
\text { diberikan } \\
\text { guru yang } \\
\text { berisi tentang } \\
\text { materi } \\
\text { pembelajaran }\end{array}$ & 21,43 & $\begin{array}{c}20,36- \\
22,5\end{array}$ \\
\hline $\begin{array}{l}\text { Menanyakan } \\
\text { kepada guru } \\
\text { yang belum } \\
\text { dimengerti }\end{array}$ & 14,28 & $13,57-15$ \\
\hline $\begin{array}{l}\text { Mengerjakan } \\
\text { tugas LKS }\end{array}$ & 11,90 & $10,86-12$ \\
\hline $\begin{array}{l}\text { Siswa } \\
\text { berdiskusi }\end{array}$ & 7,14 & $10,86-12$ \\
\hline $\begin{array}{l}\text { Siswa } \\
\text { mempresenta } \\
\text { sikan hasil } \\
\text { pekerjaannya }\end{array}$ & 14,28 & $13,57-15$ \\
\hline $\begin{array}{l}\text { Perilaku yang } \\
\text { tidak relevan }\end{array}$ & 3,57 & $0-5$ \\
\hline $\begin{array}{l}\text { Isi video ini } \\
\text { menyajikan } \\
\text { masalah-masalah } \\
\text { yang } \\
\text { berhubungan } \\
\text { dengan aktivitas } \\
\text { kehidupan } \\
\text { sehari-hari }\end{array}$ & ah & $92 \%$ \\
\hline $\begin{array}{l}\text { Video ini } \\
\text { membantu saya } \\
\text { lebih mudah }\end{array}$ & 43 & $86 \%$ \\
\hline
\end{tabular}




\begin{tabular}{|c|c|c|c|}
\hline $\begin{array}{l}\text { menemukan } \\
\text { konsep dan } \\
\text { rumus sederhana } \\
\text { barisan dan deret } \\
\text { aritmetika } \\
\end{array}$ & & & \\
\hline $\begin{array}{l}\text { Video ini } \\
\text { memiliki contoh } \\
\text { soal dan } \\
\text { penjelasan yang } \\
\text { mudah dipahami }\end{array}$ & 50 & 0 & $100 \%$ \\
\hline $\begin{array}{l}\text { Video ini } \\
\text { membuat } \\
\text { pembelajaran } \\
\text { hari ini sangat } \\
\text { menyenangkan }\end{array}$ & 48 & 2 & $96 \%$ \\
\hline $\begin{array}{l}\text { Video ini } \\
\text { membuat } \\
\text { pembelajaran har } \\
\text { ini lebih } \\
\text { bermakna cepat } \\
\text { di ingat daripada } \\
\text { pembelajaran } \\
\text { sebelumnya }\end{array}$ & 45 & 5 & $90 \%$ \\
\hline $\begin{array}{l}\text { Materi } \\
\text { pembelajaran } \\
\text { pada video } \\
\text { sesuai dengan } \\
\text { contoh soal } \\
\text { dalam } \\
\text { kehidupan } \\
\text { sehari-hari }\end{array}$ & 50 & 0 & $100 \%$ \\
\hline
\end{tabular}

3) Tes hasil belajar siswa diikuti oleh 40 siswa mendapatkan hasil tes 35 siswa tuntas diperoleh persentase $87,5 \%$ dan 5 siswa lainnya belum tuntas diperoleh persentase 12,5\%. Dengan demikian bisa disimpulkan bahwa ketuntasan siswa secara klasikal diperoleh persentase $87,5 \%$ sehingga media pembelajaran video bus math menggunakan aplikasi video scribe matematika memenuhi kategori tuntas secara klasikal dan tidak perlu direvisi. Bberdasarkan hasil yang diperoleh diatas pengembangan media pembelajaran video bus math menggunakan aplikasi video scribe berbasis saintifik dikatakan baik dan efektif karena mencapai 5 indikator yaitu : penilaian para ahli valid, kemampuan guru dalam mengelola pembelajaran efektif, aktivitas siswa yang dilakukan efektif, respons siswa menyatakan positif dan ketuntasan siswa tuntas secara klasikal.

\section{SIMPULAN}

Pengembangan media pembelajaran video Bus Math (Business Mathematic) menggunakan aplikasi video scribe berbasis saintifik pada materi barisan dan deret kelas XI semester ganjil dengan menggunakan model 4-D yang dimodifikasi menghasilkan media pembelajaran yang baik karena memenuhi (1) kategori efektif untuk kemampuan guru mengelola pembelajaran, (2) kategori efektif untuk aktivitas siswa dalam pembelajaran, (3) kategori positif untuk respons siswa terhadap media pembelajaran, dan (4) memenuhi kategori ketuntasan. Adapun media pembelajaran yang dihasilkan berupa video Bus Math (Business Mathematic) menggunakan aplikasi video scribe berbasis saintifik pada materi barisan dan deret kelas XI. 


\section{DAFTAR PUSTAKA}

Daryanto.

(2014).

Pendekatan

Pembelajaran Saintifik Kurikulum 2013. Yogyakarta: Gava Media.

Dellyardianzah. (2017). Penggunaan Media Pembelajaran Berbasis Video Scribe Untuk Meningkatkan Hasil Belajar Siswa. Jurnal Pendidikan Ekonomi Akuntansi FKIP Untan Pontianak, 1-2.

Fransisca, I. (2018). Pengembangan Media Pembelajaran Video Berbasis Sparkol Videoscribe Pada Pelajaran IPA Dalam Materi Tata Surya Kelas VI SD. J-PGSD. Volume 06 Nomor 11 Tahun 2018, 1916-1927 , 1917-1918.Kholidin. (2017). Pengembangan Media Pembelajaran Menggunakan Program Video Scribe Sparkol Pada Mata Pelajaran Sejarah. Jurnal FKIP Unsri , 2-3.

Kholidin. (2017). Pengembangan Media Pembelajaran Menggunakan

Program Video Scribe Sparkol Pada Mata Pelajaran Sejarah. Jurnal FKIP Unsri , 2-3.

Musfiqon. (2015). Pendekatan Pembelajaran Saintifik. Sidoarjo: Nizamia Learning Center Sidoarjo.

Nurdyansyah. (2015). Pendekatan Pembelajaran Saintifik. Sidoarjo: Nizamia Learning Center Sidoarjo.
Oktavianingrum,
D.
(2016).

Pengembangan Media Audio Visual Sparkol Dalam Pembelajaran Mengelola Rapat Pertemuan DI LPP IPMI Kusuma Bangsa Surakarta. Jurnal Perpustakaan Uns , 3.
Prihadi, B. (2014). Penerapan LangkahLangkah Pembelajaran Dengan Pendekatan Saintifik Dalam Kurikulum 2013. Jurnal In House Traning Implementasi Kurikulum $2013,1-5$.

Ritna. (2013). Meningkatkan Hasil Belajar Siswa Kelas IV Dalam Pembelajaran IPS dengan Menggunakan Media Gambar di SD Inpres III Tada . Jurnal Kreatif Tadulako Online, Vol 1(No 1) , 32.

Rochmah, A. (2017). Penggunaan Media Videoscribe Untuk Meningkatkan Hasil Belajar Siswa Pada Mata Pelajaran Pengantar Administrasi Perkantoran. Jurnal Pendidikan Ekonomi , 2.

Sari, N. (2018). Perangkat Pembelajaran Matematika Yang Berbasis Pendekatan Realistic Mathematic Education Sebagai Pendukung Implementasi Kurikulum 2013 Pada Materi Sistem Aritmatika Sosial. Jurnal Skripsi , 48-58.

Sudjana, N. (2011). Penilaian Hasil Belajar Mengajar. Bandung : PT Remaja Rosdakarya.

Sugiyono. (2012). Penelitian Resarch and development. Bandung: ALFABETA.

Sutrisno, T. (2016). Pengembangan Media VideoScribe Berbasisi ELearning pada Mata Pelajaran Komunikasi Data dan Interface di SMK Sunan Drajat Lamongan. Jurnal Pendidikan Elektro , 5-10 .

Taufiq, F. R. (2016). Pengembangan Media Materi Keadaan Alam Di Indonesia Menggunakan Perangkat Lunak Pelajaran IPS 
Kelas VII. Jurnal Keguruan Dan Ilmu Pendidikan, 2.

Trianto. (2014). Mendesain Model Pembelajaran Inovatif-Progresif. Jakarta: kencana Prenada media group.

\section{PROFIL SINGKAT}

Penulis pertama lahir di Bangkalan pada tanggal 31 Mei 1983. Menempuh pendidikan S1 MIPA Matematika di Universitas Brawijaya Malang lulus tahun 2005, S2 Pendidikan Matematika di Universitas Negeri Surabaya lulus tahun 2015 dan saat ini sedang menempuh pendidikan S3 di Pendidikan Matematika Universitas Negeri Surabaya sejak Tahun 2019. Sampai saat ini penulis menjadi dosen pendidikan matematika di STKIP PGRI Bangkalan. Penulis aktif dalam tri dharma perguruan tinggi dan mendapat dana hibah penelitian dan pengabdian kepada masyarakat. Selain itu penulis sudah menerbitkan buku ber-ISBN pada tahun 2017 dan sudah membuat karya yang sudah di HKI berupa 3 media pembelajaran. 